\title{
STUDY OF DISTINGUISHING FEATURES OF PAKISTANI STANDARD ENGLISH
}

\author{
Ameer Ali ${ }^{1}$, Abdul Wahid Samoon ${ }^{2}$, Mansoor Ali $^{3}$ \\ ${ }^{1,2}$ Applied Linguistics at the University of Sindh, Jamshoro, ${ }^{3}$ English at College Education and \\ Literacy Department Sindh. Pakistan. \\ ameer7037@gmail.com ${ }^{1}$, samoonwahid@gmail.com², halajmansoorali@gmail.com ${ }^{3}$
}

\begin{abstract}
The current research has adopted a qualitative approach to investigate the linguistic differences of Pakistani Standard English in contrast to British Standard English. We studied morphological, lexical, and hybrid characteristics of Pakistani Standard English. Besides, we investigated the linguistic features to prove the fact that cultural context determines the use of a language. Moreover, the findings of this research also support the fact that a language keeps evolving in different contexts leading to the development of different varieties of the language. However, the researchers have studied comparatively many varieties of Englishes, but this research investigates the distinguishing features of Pakistani Standard English employing secondary data from Dawn e-newspaper. Additionally, the researchers have also qualitatively codified the data into broader themes. The findings of this research will help readers in understanding the role of a cultural context in developing a new variety of a language. Consequently, they will be able to carry out further research in the field of World Englishes. Hence, this research is a systematic investigation of Pakistani Standard English and its differentiating features.
\end{abstract}

Keywords: Englishes, varieties, Pakistani Standard English, different contexts.

\begin{abstract}
ABSTRAK
Penelitian ini telah mengadopsi pendekatan kualitatif untuk menyelidiki perbedaan linguistik Bahasa Inggris Standar Pakistan berbeda dengan Bahasa Inggris Standar Inggris. Para peneliti mempelajari karakteristik morfologi, leksikal, dan hibrida dari Bahasa Inggris Standar Pakistan. Selain itu, peneliti menyelidiki fitur linguistik untuk membuktikan fakta bahwa konteks budaya menentukan penggunaan suatu bahasa. Selain itu, temuan penelitian ini juga mendukung fakta bahwa suatu bahasa terus berkembang dalam konteks yang berbeda yang mengarah pada perkembangan ragam bahasa yang berbeda. Namun, para peneliti telah menemukan ragam bahasa Inggris secara komparatif, tetapi penelitian ini menyelidiki fitur yang membedakan Bahasa Inggris Standar Pakistan dengan menggunakan data sekunder dari surat kabar elektronik Dawn. Selain itu, para peneliti juga secara kualitatif mengkodifikasi data menjadi tema yang lebih luas. Temuan penelitian ini akan membantu pembaca dalam memahami peran konteks budaya dalam mengembangkan ragam bahasa baru. Dengan demikian, mereka dapat melakukan penelitian lebih lanjut di bidang Bahasa Inggris Dunia. Oleh karena itu, penelitian ini adalah penyelidikan sistematis yang membedakan antara Bahasa Inggris Standar Pakistan dan fitur-fiturnya.
\end{abstract}

Kata kunci: Bahasa Inggris, varietas, Bahasa Inggris Standar Pakistan, konteks berbeda.

\section{INTRODUCTION}

Cultural context plays a pivotal role in shaping and developing a language or its variety. Whenever a language encounters a new socio-cultural context, it gradually starts changing and thereby adapting to the new cultural reality. The language change 
occurs so that it may enable its new users to express their cultural reality conveniently (Kachru, 1987: Clyne, 1987: Tarone and Yule, 1987). These scholars have also investigated the phenomenon comprehensively. Their findings in different contexts stand by the fact that culture shapes the evolving nature and structure of a language in different circumstances.

Furthermore, a new language variety that develops in a new cultural context encounters regional linguistic influences which also determine its development and evolution. (Mehboob, 2009) has also revealed the reality by investigating the interaction of Pakistani English with the Urdu language. His research findings show that Pakistani (then Indian) English came into being when the British colonizers came to the subcontinent (Mehboob, 2009). He further elaborates that Pakistani English has been developing constantly since the separation of the subcontinent in 1947 by borrowing Arabic vocabulary from the Urdu language (Mehboob, 2009). In this way, cultural circumstances change the shape and form of a language.

(Baumgardener, 1993), these morphological characteristics are also visible in spoken Pakistani English. Similarly, (Mehboob, 2004) also comes up with the same findings which show that Pakistani English has the influence of Urdu, Arabic, and Persian languages which shape it as a specific variety of English. In short, these morphological interferences from the local languages have influenced the development of Pakistani English.

When the British colonizers came to the subcontinent, they introduced English as an official language of India. This policy decision entailed the interaction between the British Standard English and the local languages of India. Thus, in the new cultural reality, Indian English as a variety of English developed to facilitate the local users. When the colonizers left the subcontinent, India and Pakistan came into being as two separate states in 1947. Consequently, Pakistani English developed in the new cultural context. Moreover, Pakistani English has linguistic features which many speakers of British English find it hard to understand; hence, many scholars (Mehboob, 2004; Rehman, 2010) have studied and systematically addressed this linguistic particularity. If Pakistani English is researched and enriched, it can serve as a tool to counter the discourses of hegemony. Thus, the current research has made use of a qualitative approach to investigate the differences between Pakistani English and British English.

The current research is significant because it has explored the various dimensions of differences between the two varieties of English in a comprehensive manner. This will enable many researchers to research this pattern in different 
cultural contexts of World Englishes. Besides, this has also added new findings to the field of World Englishes. Finally, the current research is a compact attempt at understanding the linguistic features of Pakistani English in contrast to British English. This research paper addressed about, what are the morphological, hybrid, and lexical features of PSE?, why have linguistic differences emerged in PSE?, and how does cultural context determine the form and shape of PSE?

Research Delimitation: The current research is delimited to the morphological, hybrid, and lexical differences of PSE.

Theoretical Framework: (Weinreich, 1953), when two different languages interact in a new cultural reality, they gradually tend to influence each other in a way that they produce a different variety of a language. This cultural-specific interaction paves the way for new linguistic processes which ultimately form a new language variety. This variety of language develops due to what Weinreich (quoted in Rehman, 2010) has called "interference". He argues that 'interference' involves a process in which the morphemes of language A transfer to language B; alternatively, the B language designates new functions of its morphemes on the model of A-language morphemes. Moreover, Pakistani English has borrowed many of its lexical morphemes from Urdu and Arabic languages, and this is the fact which distinguishes it from Indian English and British English. Therefore, this research paper has discussed how Pakistani English has interference from the Urdu language.

\section{LITERATURE REVIEW.}

While studying the South Asian variety of British English, researchers have often centred their attention to Indian English (Leitner, 2012; Halliday, 1974; Kachru, 1986). These researchers have mostly considered South Asian languages as a coherent whole. It was the work of the successive scholars who managed to bring out the different varieties of South Asian English to the light. For the first time, there was a questionnaire survey concerning English language teaching problems when Pakistan was mentioned separately (Bickley, 1982). Bickley (1982) pointed out the fact that there were different problems which teachers and learners of English in Pakistan faced on a daily basis. This research work served to establish the hypothesis that there is a different variety of English in Pakistan which must be dealt with in the context-specific manner.

By building upon Bickley's hypothesis (1982), many researchers undertook the task of studying the phenomenon, however, their attempts were not well directed. 
Finally, the time came when researchers started exploring English language problems in the context of Pakistan. In this regard, there was further research in Pakistan's context which found out the typical linguistic characteristics of English in Pakistan, and the country was finally included in the list of ESL countries (Campbell, 1932). Then, the research practices became much more focused. Kachru wrote a research paper in 1984 in which he elaborated upon his earlier views by referring to the different varieties of South Asian English: Indian English, Sri Lankan English, and Pakistani English (1986). Moreover, he also cites examples from Pakistani newspapers to develop the culture-specific view of the language (1986). In this manner, the researchers managed to identify PE as a separate, nonnative variety of $\mathrm{BE}$.

Apart from identifying PE as a separate variety of BE, research scholars working in the field have also studied the linguistic forces which have contributed to the development of PE. There is a prominent research work which shows that PE has developed differently to comply with the country's cultural reality. Unlike Indian English, Pakistani English is shaped by Islam and Muslim History (Rehman, 2010). (Rehman, 2010) means to imply that PE is different from Indian English because the former derives its terminology from Islamic register. Additionally, Rehman's work is an innovative contribution to the field of PE, because it has described the nature of $\mathrm{PE}$ along with its different regional varieties. His work establishes the fact that even in Pakistan there are varieties of PE, such as Sindhi English, Punjabi English, Pushto English, and Balochi English.

Researchers have not only found out the different varieties of PE but also, they have discovered different approaches to teaching PE in the new cultural reality. One of these approaches is to teach PE using newspapers. Baumgardener (quoted in Rehman, 2010) advocates the view that PE might be taught effectively through PE newspapers. Although Baumgardener (1987) endorses the view that PE might be taught through PE newspapers, he does not mention the fact that there are even varieties of PE. Moreover, he has also defined PE as a non-native variety of English (Baumgardener, 1987 mentioned in Rehman, 2010). Much like Rehman (2010), Baumgardener is also of the view that $\mathrm{PE}$ is a variety of $\mathrm{BE}$, however, the different cultural context has molded its evolution differently. Thus, there are different ways of teaching different varieties of Englishes considering the concerned cultural context.

In addition to this, there is another study which has investigated the stress pattern system of Pakistani English. This time researchers from Pakistan took the challenge and conducted convincing research, however, there were some flaws in their work which were mentioned and criticized later. Usmani, a Pakistani researcher, 
studied the stress pattern of PE in the cultural reality of Pakistan (quoted in Rehman, 2010). There were some serious defects in his work. Thus, Kachru assessed his work as misleading and native in nature (Kachru, 1969). Consequently, the research zeal continued to expand upon Usmani's work, and there was another scholar who carried out pioneering work in the field. (Rehman, 2010) built upon the research gap who not only studied Pakistani English but also its varieties in the cultural reality of Pakistan. Hence, the research work on PE developed systematically.

With the passage of time and the development of PE, the research in the field grew much more focused than before. Researchers, then, started looking at the Urdu factor which influenced the development of PE. In this regard, Baumgardener took the task in his hands again and authored Urduization of English with the assistance of Fauzia Shamim (Baumgardener, et. al., 1993: Shamim, et. al., 2016). Later, he further expanded upon the "Urduization" by researching people's attitudes. Baumgardener made a huge contribution by carrying out a survey on the acceptability of PE among teachers and journalists (Baumgardener, 1995). The research work did not stop there, but it went on to further exploring different dimensions of PE. It was Ahmar Mahboob who took the task at that time and contributed to PE by writing book chapters and articles (Mahboob 2002, 2004; 2009). His works have filled a new spirit in the field of PE, and he has also explored different domains of the field.

The above review of the related literature shows that PE is a variety of English which has been studied by many scholars from different dimensions at different times. These scholars have indeed systematically contributed to the field, however, there is need of further research to explore the distinguishing features of PE in an evolving cultural context, so this research fills up the gap by studying the updated features of Pakistani English in the twenty-first century using Weinreich's concept of interference. We have, thereby, employed secondary data to investigate the linguistic features of PE, such as morphological items, hybrid terms, and lexical items which differentiate it from other varieties of English including BE. Thus, the current research has explored the distinguishing linguistic features of PE using a qualitative approach and data.

\section{RESEARCH METHOD}

The current research employed a qualitative method to investigate the distinguishing features of Pakistani English. The use of qualitative, secondary data has made this research comprehensive and relevant. Simultaneously, the use of the qualitative method has enabled the researchers to code data into broader themes and 
analyze accordingly. The research design of this paper is qualitative. This design has enabled the researchers to explore the features of PE effectively. The researchers have chosen the qualitative design because it facilitates in-depth investigation (Creswell, 2012). The qualitative interpretations of language change and variety help define the processes of linguistic evolution. The researchers have used a purposive sampling tool to collect data from Dawn epaper. Simultaneously, the researchers have also made use of thematic analysis to identify the distinguishing features of PE. The selection of thematic analysis has been made considering the qualitative nature of the research problem.

\section{FINDINGS AND DISCUSSION}

In this segment, the analysis of data has been carried out based on morphological, lexical, and hybrid features of PE which distinguish it from other varieties of English.

\section{The Distinguishing, Morphological Features of PE:}

\subsection{Interference of Suffix 'Ation' in Pakistani English}

Pakistani English (PE) has proclaimed its distinguished identity by designating the new functions of morphemes. There are morphological characteristics in Pakistani English which have brought forth new words which are not found in other varieties of English. The suffix "ation" has been used in Dawn newspaper with nouns, such as "point". This interference is unique to PE as it gives birth to the word "pointation" (Dawn, 2015) which implies "to furnish someone with information". Consequently, it is no wrong to say that the word "pointation" solely belongs to Pakistani English. There is no place for this word in the other varieties of English around the world. It is the cultural reality of Pakistan that has facilitated these types of morphological changes to create new words as discussed by Weireich.

\subsection{Interference of Local Prefixes and Suffixes in Pakistani English:}

Moreover, there are many words with this type of unique morphological structure which one can usually find in Pakistani English, however, these very words are unknown to the native speakers of English language. The words, such as "deshape", "deload", and "eveninger" are unique neologisms of PE. Furthermore, the derivational morphemes also tend to merge with Urdu or any other local language bases, and thus formulate new words. For instance, there is 'ism' a derivational suffix which as Weinreich had said interferes with Urdu bases, such as "baradari" "gunda" to neologize "baradarism" and "gundaism". In this way, the generalized use of 
morphemes in the cultural reality of Pakistan has formulated new words which cannot be found in the other varieties of English.

\subsection{Interference of Local Productive Suffixes in Pakistani English:}

Much like these derivational suffixes, there are some other productive suffixes which are also generously used in Pakistani English; however, these same suffixes are used in a very restricted manner in the countries where English is a native language. the use of these suffixes is made in a creative manner when it comes to the cultural context of Pakistan. The suffixes "er" and "ee" are interfered with English bases, such as "affect", "shift", or "lift" to make "affectee", "shiftee" and "motorcycle lifter" (Dawn, 2018). These examples also confirm Weinreich's statement of interference. Though these words are easily understood by the speakers of the Pakistani language, the native speakers will not be able to understand these words. Pakistani speakers are quite open with morphological coinage, because sometimes they cannot find the British English equivalent to refer to their cultural reality, so they usually rely on these productive suffixes to deal with the situation in a creative manner. In this context, Pakistani speakers negotiate with their social dilemmas by making creative use of derivational morphemes. Besides, these derivational morphemes are attached with the name of a person to refer to that person's way of life. The suffix "ism" is used with the name of Zia ul Haq to make "Ziaism" which refers to his policies in a sarcastic manner. Even a person who follows the tenets of Zia would be labelled "Ziaist" (Hussain, 2019). Similarly, there are other coinages, such as “Bhuttoism” (Almeida, 2012), “Mullahism" (Dawn, 2016), and “ad hocism” (Khan, 2009), however, one can easily find these words in Pakistani English newspapers, such as Dawn, but there are no chances at all that a person will find the same words in the other cultural contexts except that these ideas have made their influence and interference in the concerned cultural context.

\subsection{Interference of Local Free Morphemes in Pakistani English}

In addition to these derivational morphemes, the independent, lexical morphemes from both regional languages and Pakistani English also combine to make new words. This influence of the local languages has determined the shape of Pakistani English in a much more different manner than British Standard English. There are many words such as "lathee charge" (Waqar, 2020), "roti price" (Raza,2019), "richshaw-wala” (Booya, 2014), “car-wala”, etc. The words, such as "charge", "price", and "rickshaw" are from English, while the words, such as "lathe", "roti", and "wala" are from the Urdu language. In the context of Pakistan, they have merged with each other to create new hybrid words which have different 
meaning and concepts associated with them from the ones associated with their bases. This is also a creative usage of languages. In this instance, languages are interfering and creatively interacting with each other. In the contextual reality of Pakistan, the languages are enriching each other. These hybrids are not only restricted to Pakistani English, but they are also used with an equal frequency in the Urdu language. However, once again, researchers cannot find these words in other cultural contexts, because these are the products of the cultural reality of Pakistan. There are many such hybrid words which one will find unique to Pakistani English.

\section{The Distinguishing Lexical Features of Pakistani English:}

Apart from these morphological differences, Pakistani English is also enriched with the lexical items which add to its variety. Since Pakistani's society is multilingual in its formation, new words from these languages keep entering Pakistani language. The continuous process has indeed led to the development and evolution of Pakistani English in a very different way. These linguistic interferences have given PE new forms and words which add to its richness and beauty. The multilingual variety is the cultural context where Pakistani English meets different languages in an organic way whose interference has given the language new directions of evolution and development. However, this process of development and evolution has always been two-way. In the following paragraphs, the lexical items which have interfered with PE from the regional languages are discussed systematically.

The lexical items from the regional languages have diversified the vocabulary of Pakistani English in contrast with British English or other varieties of English. Most of these lexical items have entered PE from Urdu. There is a word "katchi abadi” which PE has borrowed from Urdu. Dawn reports: “...to relocate people from illegally set up katchi abadis...” (Sahoutara, 2020). PE has naturalized this word completely. There are both singular and plural forms of this borrowed word in PE. In the above instance, the word has been used plurally. The regulations of pluralization have moulded the borrowed word so that it may fit naturally in its new home and linguistic context which is no doubt PE. Moreover, there are also other words of Urdu which PE has borrowed generously to enrich its vocabulary and thereby allow its speakers to express themselves conveniently in the Pakistani context. The word is "Urs" which is used in Sindhi as well as the Urdu language. Pakistani English has also internalized the word in a very natural manner. The prestigious newspaper of the country, Dawn writes: “The book comprises poems and research papers presented during the Mushaira and Literary Conference held on the last Urs of Bedil " (Dawn, 2007). The word "Urs" refers to the birthday 
anniversary of a saint. In the same article, another lexical item has been used which PE has borrowed from Urdu as well (Dawn, 2007). The word is "mehfil-e-sama" which means a concert of Sufi music. Thus, Pakistani English has been enhancing its scope and vocabulary.

There are also many other lexical items which PE has been borrowing from the regional languages to facilitate its speakers to express themselves easily in their own cultural context. This contextualization of Pakistani English has indeed put many of its speakers at ease by borrowing from their own languages. In this regard, there is the word "mushaira" which means a literary gathering where people recite their poetry. The word has now become a part and parcel of Pakistani English as well. Dawn has also utilized the word: "Rahman Faris was the first poet to take the stage. He set the tone of his stint there by reciting a couplet which paid tribute to the host (nazim) of the mushaira..." (Dawn, 2020). The borrowing of this literary word also shows the fact that it is the quality of literary languages that they always borrow literary, expressive, words from other languages. In this regard, Pakistani English has also relied upon the Urdu language to borrow the concerned word so that its speakers can easily talk about the literary context of Pakistan. Additionally, there are also traditional food items which English speakers cannot talk about without borrowing the words from the local languages. In this social dilemma, Pakistani English has also borrowed from local languages to refer to these items of food. Dawn (Yasin, 2016) talk about "samosas", "pakoras", and "kachoris" which are being sold in the hot weather. It is interesting here to notice the pluralization of these borrowed words. It shows that these words have not fully naturalized in the linguistic context of Pakistani English. Thus, Pakistani English has naturalized many words which it has borrowed from the local languages.

Not only these food items but also other words which show social identities have also made their way from the regional languages of Pakistan into Pakistani English. These words have also enabled Pakistanis to question their social realities and resist oppressive identities. The word "Wadera" is of a Sindhi origin, however, it figuratively refers to a dog in the manger mindset. This mindset can be found in many areas of Pakistan. Dawn has reported and used the word: "the issue of wadera/tribal justice is quite complicated..." (Rehman, 2014). The use of "wadera" in this daily shows that Pakistani English has also internalized the word from Sindhi language to allow its speakers from Sindh to talk about the mindset, identity, or individual concerned. This internalization is also beneficial for Pakistani speakers because it allows them to understand the typical "wadera" mindset and thereby equips them to resist it. Moreover, there are also other words related to vocal arts which PE has also 
borrowed from the Urdu language. There is the word "Qawwali" which has come from the Urdu language into Pakistani English. Dawn e-newspaper writes: "But this generation is aware of qawwali..." (Noorani, et. al., 2016). The word "qawwali" refers to the person who sings qawwali as well as to the song he/she sings. In this way, many words from regional languages have come into Pakistani English which is evolving to new directions in contrast to British Standard English. Similarly, there are also other words from local languages which stand for musical instruments have also taken their places in Pakistani English. Once again Dawn shows the tendency: “...the instrumentalists played dhol, tabla, clarinet and sitar" (Dawn, 2017).

Finally, all the above discussions show that Pakistani English has indeed borrowed many lexical items from the regional languages to enrich itself and facilitate the local speakers to easily express their cultural reality. In this multilingual context, Pakistani English will keep evolving into new forms and shapes in contrast to British Standard English or the other Englishes which are spoken in the different contexts of the world.

\section{CONCLUSION}

Thus, it is finally concluded that Pakistani English has borrowed lexical items from the interfering regional languages, and it has also enriched itself through wordformation processes with the assistance of derivational and functional morphemes. Pakistani English has creatively interacted with the local languages mainly with Urdu. We found out that many prefixes and suffixes from the Urdu language have interfered with Pakistani English. In other words, many of Urdu morphemes have also interfered with Pakistani English in almost the same way as Weinreich had suggested in 1953. Similarly, Urdu lexical features have also found their way into Pakistani English making it a unique variety among world Englishes. We have been of the view that all these morphological and lexical features of Pakistani English place it in a very distinguished place which reflects the local cultural reality. Pakistani English will keep developing and evolving by interacting with the regional languages in the contextual reality of Pakistan. This will provide its speakers with powerful discourses to resist international, hegemonic discourses by developing their cultural variety and integrated identity. Moreover, this research paper will also enable many research scholars to explore the linguistic features of Pakistani English using corpusbased approaches. Finally, this research is a collective effort of three scholars who claim no absolute truth in terms of their findings. The researchers are hopeful that this research paper will open new directions for further research in the field of Pakistani English. 


\section{BIBLIOGRAPHY}

Waqar, Ali. (2020, August 12). PML-N workers, police clash outside NAB office in Lahore before Maryam's hearing. Retrieved from https://www.dawn.com/news/1573841/pml-n-workers-police-clash-outsidenab-office-in-lahore-before-maryams-hearing

Almeida, C. (2012, April 7). The flip side of Bhuttoism. Retrieved from https://www.dawn.com/news/708774/the-flip-side-of-bhuttoism

Noorani, Asif., Ahmed, Nafees., Yousuf Zai, T. Y., Moini, Q. A., Mazhar, Rabia. (2016, July 24). Qawwali is here to stay. Retrieved from https://www.dawn.com/news/1272441

Baumgardener, R. J. (1996). Pakistani English: Acceptability and the norm. https://www.researchgate.net/publication/229529112_Pakistani_English_Acc eptability_and_the_norm

Bedil's urs on 25th. (2007, November 4). Retrieved from https://www.dawn.com/news/274215/bedil

BERNS, M. (2015). Pedagogy and world Englishes: The legacy of Yamuna Kachru. World Englishes, 34(1), 22-30. doi:10.1111/weng.12113

BICKLEY, V. C. (1982). Language as the bridge. Cultures in Contact, 99-125. doi:10.1016/b978-0-08-025805-8.50013-5

Booya, T. (2014, March 27). Rickshaw run. Retrieved from https://www.dawn.com/news/1085119

Campbell, O. J. (1932). English majors and others. The English Journal, 21(3), 206. doi:10.2307/804075

Creswell, J. W. (2012). Educational research: Planning, conducting, and evaluating quantitative and qualitative research. Pearson Education.

Editor's note. (2012). English World-Wide, 33(1), 125-125. doi:10.1075/eww.33.1.11not

Halliday, E. M. (1974). Confidence in the morning. College English, 35(6), 707. doi:10.2307/375258

Hussain, Z. (2019, October 23). From blank pages to blackout. Retrieved from https://www.dawn.com/news/1512404

Kachru, B. B. (1986). The alchemy of English: The spread, functions, and models of non-native Englishes. University of Illinois Press.

Kachru, B. B. (1986). The indianization of English. English Today, 2(2), 31-33. doi:10.1017/s026607840000198x

Kachru, Y. (1969). Hindi-Urdu-Hindustani. Language in South Asia, 81-102. 
doi:10.1017/cbo9780511619069.006

KACHRU, Y. (1987). Preface. World Englishes, 6(3), 189-190. doi:10.1111/j.1467971x.1987.tb00198.x

Khan, A. F. (2009, February 6). Heads of six distribution companies on extension: Adhocism hits Pepco. Retrieved from https://www.dawn.com/news/342075/newspaper/column

MAHBOOB, A. (2009). English as an Islamic language: A case study of Pakistani English. World Englishes, 28(2), 175-189. doi:10.1111/j.1467971x.2009.01583.x

Mahboob, A. (n.d.). Pakistani English. The Mouton World Atlas of Variation in English. doi:10.1515/9783110280128.531

The Newspaper's Staff Reporter. (2015, January 17). Wire. Retrieved from https://www.dawn.com/news/1157524

The Newspaper's Staff Reporter. (2016, April 15). Sufism promotes love and tolerance. https://www.dawn.com/news/1252229/newspaper/column

The Newspaper's Staff Reporter. (2017, November 23). Classical night on the 2nd day of music conference. Retrieved from https://www.dawn.com/news/1372289

The Newspaper's Staff Reporter. (2018, June 12). Motorbike-lifters' gang busted. Retrieved from https://www.dawn.com/news/1413479

PPI. (2020, February 15). Mushaira held at Karachi University in memory of Salimuzzaman Siddiqui. Retrieved from https://www.dawn.com/news/1534477/mushaira-held-at-karachi-universityin-memory-of-salimuzzaman-siddiqui

Publications received. (1987). World Englishes, 6(2), 187-187. doi:10.1111/j.1467971x.1987.tb00197.x

Rahman, T. (1990). Pakistani English: The linguistic description of a non-native variety of English.

Rahman, T. (2010). Language policy, identity, and religion: Aspects of the civilization of the Muslims of Pakistan and North India.

Raza, S. I. (2019, July 31). Imran orders restoration of previous naan, roti prices. Retrieved from https://www.dawn.com/news/1497185

Rehman, I. (2014, March 27). No end to wadera justice? Retrieved from https://www.dawn.com/news/1095805

Reviews. (1993). World Englishes, 12(3), 415-424. doi:10.1111/j.1467971x.1993.tb00039.x

Sahoutara, N. (2020, February 21). Centre, Sindh told to consult experts on 


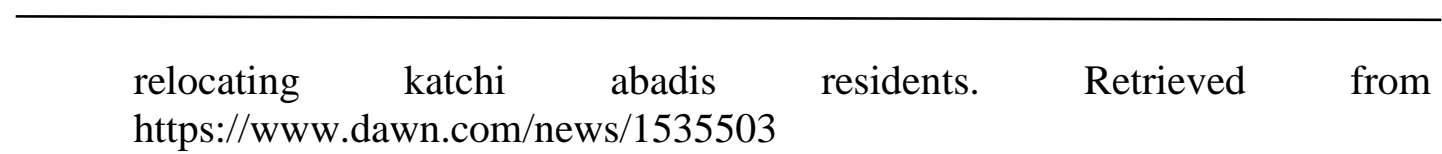

Shamim, F., Abdelhalim, A., \& Hamid, N. (2016). English medium instruction in the transition year: Case from KSA. Arab World English Journal, 7(1), 32-47. doi:10.24093/awej/vol7no1.

Weinreich, Uriel. 1953. Languages in contact. New York

Yasin, A. (2016, June 27). Feasting on pakoras, samosas and kachoris in Ramazan. Retrieved from https://www.dawn.com/news/1267511/feasting-on-pakorassamosas-and-kachoris-in-ramazan 